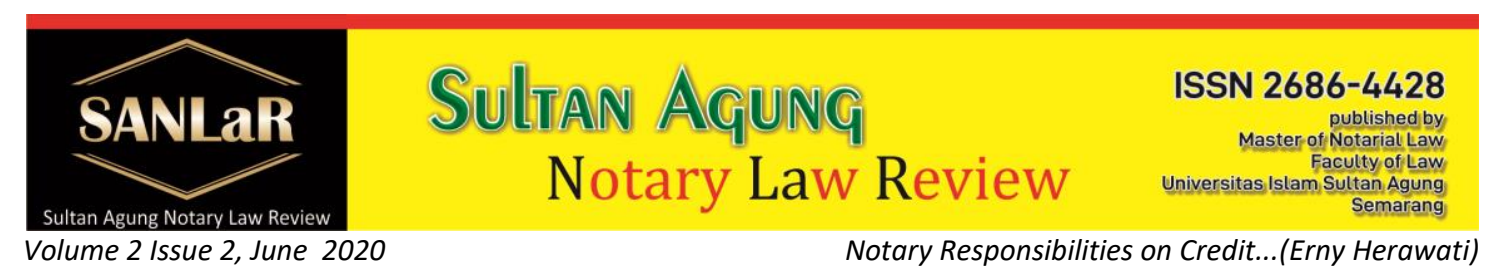

\title{
Notary Responsibilities on Credit Agreement of Building Warranties Right (HGB)
}

\section{Erny Herawati ${ }^{*}$}

*) Students of Master of Notary Law, Universitas Islam Sultan Agung (UNISSULA) Semarang, E-Mail: ernyherawati 10@gmail.com

\begin{abstract}
The purpose of this study is conducted to: 1) Analyze the responsibility of the notary in the deed that is not in accordance with the provisions of paragraph of article 16 paragraph (1) item 1 and paragraph (7), Law office of a notary. 2) Analyze the responsibility of the notary in the manufacture of a credit agreement with a guarantee deed Building Warranties Right (HGB) maturing amid financing period. The data used in this study are primary data, secondary data and data that can support tertiary study, which was then analyzed with descriptive methods analyst.
\end{abstract}

Keywords: Responsibilities; Agreement; Building Warranties Right.

\section{Introduction}

The world economy is growing rapidly raises the need for legal certainty in each of the cooperation. Deal-will appear at the beginning of the negotiations and the legal certainty needed in its implementation, to ensure legal certainty the implementation of the agreement must be poured into a written agreement in the form of an authentic deed before a public official who in this case is a notary. The agreement was made often in partnership with the financial institutions in this regard is the banks. In cooperation with the banks, especially the cooperation required financing guarantees in the form of goods not moving or moving goods. Immovable goods can be either vacant land or land with buildings standing thereon. Just like home, shop, warehouse etc. One of the requirements as there must be a guarantee that asset ownership, either in the form of certificates for goods not moving or BPKB for moving goods. Greater concern are the guarantee for the goods do not move with legalizing such land rights certificates $(\mathrm{HGB})^{1}$.

\section{Research Methods}

The method used in this study is primarily descriptive analytical approach. Descriptive analysis is research that describes an analysis of the existing findings. ${ }^{2}$ Descriptive

\footnotetext{
${ }^{1}$ Chusna, Amalia., \& Hafidz, Jawade. (2019). The Role of the Notary in the Credit Agreement with Mortgage Guarantee (Case Study in the Bank Tabungan Negara (Persero) Tbk). JURNAL AKTA: Vol. 6, No. 4, 719-726. Retrieved from http://jurnal.unissula.ac.id/index.php/akta/article/view/7668

${ }^{2}$ Soekanto, Soejono. (1986). Pengantar Penelitian Hukum. Jakarta: UI Pres.p. 51
} 
analysis approach in this study, is the approach in terms of legislation and legal norms in accordance with the existing problems.

\section{Results and Discussion}

In Article 1867 of the Civil Code states that:

Proof by writing done with an authentic writings and the writings under the hand ${ }^{3}$. An authentic deed is a deed in the form prescribed by the Act made.

In connection with the above conditions, a Notary Public officials may be authorized by law to make an authentic deed. This is also confirmed in a law office No. 30, 2004, article 1 paragraph 1 which states that the notary is a public official who is authorized to make an authentic deed and other authorities referred to in this law. As a Notary public officials need to be professional and independent (unbiased). Notaries charge will of the parties to be an agreement in a legal act (Partij Acten) or constantire a notary law in the event consists of four things, namely: ${ }^{4}$

a. Notary authorized insofar related to the notary deed made only authorized to make the authentic act civil law along not the authority of other public officials and is not authorized to make the authentic act in the field of public law.

b. Notary authorities in respect of the persons in whose interests the deed was made, a notary is not authorized to make the deed for the benefit of everyone, as stated in Article 52 of Act No. 2 of 2014 concerning amendments to the Act No. 30 of 2004 concerning Notary office.

c. Notary authorized only in respect of the place where the deed is made, in accordance with article 19 of Act No. 2 of 2014 concerning amendments to the Act 30 of 2004 concerning Notary office. Notaries are not authorized to make the deed position outside the region.

d. Only authorized notary deed all the time it was. Notaries must not be a deed in conditions still leave or dismissed.

Besides the four things that need to be associated with the notary authority, must be taken into consideration Article 1 paragraph 7 of Law Notary office and Article 1868 of the Civil Code as a condition of validity of a deed.

As for the validity of a deed requirements include:

a. These amendments must be made by / or in front of public officials.

b. These amendments should be made in the prescribed form Act

c. Public officials by / or in the presence of whom the deed was made must have the authority for the place where the deed made.

In connection with the authority that must be owned by public officials in the manufacture of an authentic deed, a notary public can only be run his position legal

\footnotetext{
${ }^{3}$ Prof. R Subekti, SH. R. Tjitrosudibio. (2004). Kitab Undang - Undang Hukum Perdata, Print. 35. Jakarta: PT. Pradnya Paramita.p. 475

${ }^{4}$ Ibid. p. 475
} 
area that has been determined, so the deed made by a notary outside the region is not a valid legal title.

The responsibility of notaries as a profession was born of their obligations and authority given to him, the duty and the authority legally and related entered into force since the notary oath of office as a notary. Oath was spoken should control all notarial acts in the running position.

Raden Soegondo Notodisoerjo establish what can be justified by a notary that if fraud or trickery was sourced from his own notary. This can occur when a transfer of rights in a transaction, for example in the deed of sale deliberately lower list prices and actual prices $^{5}$, While Nico distinguish the responsibility of the notary into four types: ${ }^{6}$

a. Notary civilly liable to the material truth of the deed he made.

b. Notary criminally liable towards the material truth in deed made.

c. Notary responsibilities pursuant to Rule Notary of the material truth in deed which made.

d. Notary responsibility in performing their duties notary office by the code of conduct.

\subsection{Notary in Civil responsibility Material against Truth Deed which he made}

Wirjono prodjodikoro said that accountability for one's actions is usually a new practical no sense if the person doing the deeds that are not allowed by law and mostly acts like it is an act in the Civil Code called tort ${ }^{7}$, Unlawful action in the broad sense if such actions:

\subsubsection{Violates the rights of others}

The statute gives the right to each person, the right in question in this case subjective recht which in principle granted to protect his interest based on the jurisprudence of the rights of the most important deign to act against the law are private rights such as the right to liberty, the right to honor and reputation good and property rights.

\subsubsection{Contrary to the legal obligations of the offender}

The legal obligations are obligations imposed by law. These obligations include the written legal obligation not only act but also does not do anything by law, if done some act or acts were contrary to what was secured by the law then it is called with conflicting legal obligations perpetrator.

\subsubsection{Contrary to good morals}

Obscenity is the norm according to the association with promiscuity in the society, because of the association live in a society is static then the yardstick of decency is not

\footnotetext{
${ }^{5}$ Notodisoerjo, Raden Soegondo. (1993). Hukum Kenotariatan Di Indonesia Suatu Penjelasan, print.2. Jakarta: Raja Grafindo Porsasta.p.229

${ }^{6}$ Nico. (2003). Tanggung Jawab Notaris Selaku Pejabat Umum. Yogyakarta: Center for Documentation and Studies of Businessn Law (CDBL)

${ }^{7}$ lbid.
} 
fixed (always changing). Things were previously considered not feasible at this time can be considered feasible, as well as things that are deemed inappropriate at this time could eventually be considered as something worthy.

3.1.4. Contrary to propriety in observing yourself and other assets already in the association of daily life:

Everyone has the same rights under the law, and therefore was already duly respect the rights of each to enjoy in everyday social life. An act done by ignoring the interests of others, it can be done has been contrary to propriety.

Decency is a very important thing to be considered by the notary in making or formulating a deed. Notaries must avoid a deed in which is defending the interests of one party by violating the interests of other parties. Notary responsible merely as a formality to an authentic deed made, therefore, a notary shall be neutral to the parties.

\subsection{Criminal responsibility is above notary deed he made}

Act No. 30 of 2004 on Notary Position (UUJN) does not regulate criminal provisions. UUJN only regulates sanctions for violators conducted by a notary to UUJN, sanctions in the form of sanctions against the deed had made and to the notary. Sanctions against the deed he made into a deed made by the notary slumming of the deed under the hand, while the notary given sanctions ranging from a reprimand to lead to a dishonorable discharge.

Crime is an act that is prohibited by a rule of law, if the violation of the ban will be followed by sanctions meant the crimes committed by the notary in his capacity as a public official authorized to make an authentic deed secured by UUJN not a personal capacity or individual of the notary as a legal subject.

The Criminal elements of actions covering ${ }^{8}$ :

\subsubsection{Deeds (human)}

Works are actions and events generated by these actions. Moeljatno believes is a human act in the elements of a criminal offense is a behavior plus events caused by the behavior. Further, he argued that:

"In criminal law, conduct or behavior that there are positive and negative. In the case of the negative person is not the defendant do something, whereas negative person is not doing something that should be done. As is the behavior is the attitude of the body, because not doing something can not be included within the meaning of such behavior is limited to physical conscious attitude alone. "

\subsubsection{Meets formulation legislation (formal requirements)}

An act can be regarded as a criminal offense if it fulfills the formulation or elements contained in the rule. It is derived from the principle of legality "Mulla Delictum Mullum Poena Sine Pravia Legepoenali"

\footnotetext{
${ }^{8}$ Anshori, Ghofur. (2009). Lembaga Kenotariatan Indonesia, Perspektif Hukum dan Etika. Yogyakarta: UII Pres.p. 38-39
} 


\subsubsection{Against the law}

In addition to the two elements above, to be categorized as a criminal offense must also satisfy the third element is the element against the law, these elements constitute an absolute element of the crime.

\subsection{Responsibilities under Notary Law}

According to Article 91 UUJN which is closing chapters expressly revoke and declare void the regulations History of the office notary, so that the compass in the implementation of the post of notary today is UUJN Responsibility Notaries in UUJN explicitly referred to in Article 65 UUJN stating that the notary (notary substitute, substitute notary notarized special and temporary officials) responsible for every deed he had done, even though the notary protocol has been assigned or transferred to the depositary notary protocol.

\subsection{Responsibility Notaries in stints His post based on the code of conduct notary}

There is a very strong correlation between UUJN with the code of professional conduct. Notary professional code of ethics set internally and Externally UUJN. According to Muhammad, as quoted by Nico, and Abdul Ghofur Anshori, a notary in carrying out his duties.

a. Notary deed required to perform properly. Meaning deed made it meets the laws and government wants the parties concerned because of his position ${ }^{9}$,

b. Notary deed required to produce quality, which means that the deed had made it in accordance with the rule of law and wants interested parties in the true sense, not making it up. Notaries have to run to the parties concerned will be the truth of the deed and procedures that made it.

Positive impact, meaning that anyone will recognize a notary deed that has the strength of evidence is perfect.

Article 1 point 1 UUJN provide Notary definition, namely as a public official authorized to make an authentic deed and other authority granted by UUJN. This article further article 15 gives details regarding the authority.

Article 15 states that:

a. Notary authorized to make the authentic act on all the deeds of the agreement, and the provisions required by legislation and or desired by the stakeholders to be stated in an authentic deed, guaranteeing date of deed, giving grosse, copy, and official copies, all of it throughout the making the deed was not also be assigned or excluded to other officials or any other person specified by law.

b. Similarly authorized notary

${ }^{9}$ Ibid. Abdul Ghofur Anshori.p. 49 
1) Certify the signatures and set a firm date in the letter under the hand by enrolling in a special book.

2) Letters posted under the hand by enrolling in special books;

3) Make copies of the original letters under the copied form hand that contains a description as written and illustrated in the letter in question;

4) Approve their compatibility with a photocopy of the original letter,

5) Providing legal counseling by deed;

6) A deed relating to defense, or

7) Creating a treatise deed auction.

c. In addition to the authority as aim in paragraph (1) and (2). Notaries have other powers stipulated in the legislation.

Examining the notary authority given in the article above, shows how important the role of the Notary in public life. The authority makes authentic deed is a deed that is shaped in accordance with the provisions of the law, made by or in the presence of the competent authority, in the place where the deed made as stipulated in article 1886 Book of the Law of Private Law is gong of authority Notaries in theory and practice.

A deed made by Notary does not necessarily constitute an authentic deed. Deed said to be authentic if it meets the elements in Article 1868 of the Civil Code.

These elements include:

a. Shaped in accordance with the provisions of the legislation

The shape of the Notary deed as expressly provided in article 38 of Law Notary who runs the form and anatomy of the notarial deed. Deed is further described as well as to any matters contained in the initial or the head of the deed, the deed bodies, as well as the end or cover deed.

b. Made by or in the presence of the authorities.

Notary is an official authorized by the general provisions of Article 1 paragraph 1 and article 15 UUJN UUJN

c. At the place where the deed made

Notaries have a clear position as stipulated in article 18 paragraph (1), and also has office area that clearly set forth in article 18 paragraph (2). Often mistaken in fulfilling the seat of the Notary and Notary region. Whereas Article 18 paragraph (1) and (2) has set it apart. The locus of the notary is a town in the district, while the region is the Notary office covers the whole of province of domicile. It should be noted by the Notary in a deed because if a certificate does not meet this requirement, it can affect the authenticity of the certificate. 
Normative explanations above show that the deed made by Notary during the manufacture of the authentic act to comply in 1868 above article is really an authentic deed.

Speaking about the authentic act can not be released by the force of proof. The purpose of the client come before Notary and ask to put it in good authentic deed to be made by a notary or by client is a legal act performed in order to obtain legal certainty. The parties can make a deal that has been poured into the authentic act provides certainty among the parties and their heirs or persons who have the right of them, a perfect proof. Article 1870 provides that the certificate is authentic certainty among the parties and their heirs or persons who have the right of them, a perfect evidence about what is contained in it.

Perfect proof strength is the strength of evidence on the evidence that led to the value proofment on the evidence that led to the evidential value to the evidence is sufficient in itself. The coverage in the sense that certain evidence did not need another book tool requires an event, the legal relationship, as well as rights and obligations. For example, a land certificate as authentic deed had perfect strength of evidence to prove a person's right to land in the certificate, without the need for witness testimony or other evidence ${ }^{10}$.

Truth in an authentic deed is not only seen on the truth of the client had been facing before the Notary as a public official, on the date mentioned in the deed, and that they have to explain what is written on the parties have to explain what is written in it, but also explained what it was ${ }^{11}$. If a party filed a deed that has really happened so that the judge may not order adds more evidence.

Although it has been described that the Notary is an official authorized to make an authentic deed but not necessarily all of a deed made by Notary automatically categorized as an authentic deed. Notary deed made before an authentic act when it meets the overall elements of Article 1868 of the Civil Code Deed.

As a result of the law is not entirely one of the elements required under Article 1868 of an authentic deed is the deed slumming into deed under hand, authenticity lost deed and no longer has the strength of evidence is perfect and the binding strength proofment be equal to the deed under the hand that is just as evidence starters.

The strength of the evidence beginning (Bewijskracht) is the strength of the evidence on the evidence that do not meet the minimum threshold of proof. In a simpler sense. Strength initial evidence is the strength of evidence that has yet to prove anythinganything. His ability to prove an event or certain facts to be supported one other evidence to meet the minimum threshold of proof.

\footnotetext{
10 Asnawi, M. Nafsir. (2013). Hukum Pembuktian Perkara Perdata Di Indonesia, Kajian Konstektual Mengenai System Asas, Prinsip, Pembenahan Dan Standart Pembuktian. Yogyakarta: UII Pres.p. 43

${ }^{11}$ Subekti. (2007). Hukum Pembuktian. Jakarta: Pradnya Paramita. p. 28
} 
Brief presentation of the notaries, notary authority and strength of evidence of the notarial deed implies that important task ascribed to a notary. The authority of the notary and the strength of evidence of the notarial deed so important tasks ascribed to a notary. The client came to before a notary have great expectations will safe and the desire to get a clear legal powers in legal acts made.

The deed which made by Notary so urgent for the parties. The agreement made by the parties and set forth in the agreement form has the same binding force tied by Law known as Pacta Sun Servanda principle. What deed is poured on law for the parties that will run it. Notary Deed are law that must be obeyed by the parties. Notary onethe only law that has such authority.

In connection with the position of the notary as a public official, the notary must be professional and independent. However, many issues that arise involving the Notary office showed that the Notary as public officials who have the authority making authentic act has not been able to work professionally in accordance with the duties and authority.

The number of cases that arise involving the notary office showed that the Notary as a public official authorized to make an authentic deed, have not been able to work professionally in accordance with the duties and authority.

\section{Closing}

Notary as public officials have a role and a great responsibility in ensuring legal certainty in the agreement entered into between the parties. Referring to the existence of the agreement, need special attention for maturities guarantee Building Warranties Right (HGB). This relates to the abolition of the guarantee HGB APHT overdue.

\section{References}

\section{Journal:}

Chusna, Amalia., \& Hafidz, Jawade. (2019). The Role of the Notary in the Credit Agreement with Mortgage Guarantee (Case Study in the Bank Tabungan Negara (Persero) Tbk). JURNAL AKTA: Vol. 6, No. 4, 719-726. Retrieved from http://jurnal.unissula.ac.id/index.php/akta/article/view/7668

Books:

[1] Anshori, Ghofur. (2009). Lembaga Kenotariatan Indonesia, Perspektif Hukum dan Etika. Yogyakarta: UII Pres

[2] Asnawi, M. Nafsir. (2013). Hukum Pembuktian Perkara Perdata Di Indonesia, Kajian Konstektual Mengenai System Asas, Prinsip, Pembenahan Dan Standart Pembuktian. Yogyakarta: UII Pres 
[3] Nico. (2003). Tanggung Jawab Notaris Selaku Pejabat Umum. Yogyakarta: Center for Documentation and Studies of Businessn Law (CDBL)

[4] Notodisoerjo, Raden Soegondo. (1993). Hukum Kenotariatan Di Indonesia Suatu Penjelasan, print.2. Jakarta: Raja Grafindo Porsasta

[5] Prof. R Subekti, SH. R. Tjitrosudibio. (2004). Kitab Undang - Undang Hukum Perdata, Print. 35. Jakarta: PT. Pradnya Paramita

[6] Soekanto, Soejono. (1986). Pengantar Penelitian Hukum. Jakarta: UI Pres

[7] Subekti. (2007). Hukum Pembuktian. Jakarta: Pradnya Paramita 